\title{
Epilepsy, a Neurological Emergency in Oro-maxi-facial Surgery - neuro - psychic Field
}

\author{
CONSTANTIN MIHAI ${ }^{1}$, CRISTIAN CONSTANTIN BUDACU ${ }^{2 *}$, ALEXANDRU TIMOFTE ${ }^{2}$, IULIAN DAN CUCIUREANU3*, \\ NORINA CONSUELA FORNA ${ }^{1}$ \\ ${ }^{1}$ Grigore T. Popa University of Medicine and Pharmacy, Faculty of Dental Medicine, 16 Universitatii Str., 700115, Iasi, Romania \\ ${ }^{2}$ Grigore T. Popa University of Medicine and Pharmacy, Faculty of Medicine, 16 Universitatii Str., 700115, lasi, Romania \\ ${ }^{3}$ Grigore T. Popa University of Medicine and Pharmacy, Faculty of Medicine, Departement III, Neurology, 16 Universitatii Str., \\ 700115, lasi, Romania
}

\begin{abstract}
Dental practice does not start with the fear for accidents and complications, much less for emergency, but in order to prevent and effectively treat them, they must be known and diagnosed quickly, correctlyand with great discernment. Fortunately, in dental practice, emergency is not met frequently, but if it occurs, however, doctor's accurate and fast reaction can and save thepatient's life. Emergency requires maximum efficiency and it imposes to give the most direct and shortest dental practice for solving. It is possible to trigger or aggravate generaldisorders caused by dental work, cases in which we have an obligation to recognize the accident or complication at the time of happening and to intervene urgently and effectively to save the patient's life. Epilepsy is a neurological disease that alters the transmission of electrical signals within the brain. We conducted our study in the Oral and Maxillofacial Surgery Clinic on 187 patients studied between 2015 and 2018. Of these, 171 were emergencies. Regardingthe interventions suffered by the patient, it was observed that the most common neurological emergency installed in dentistry is the epileptic seizure. Serious and small epileptic seizures can occur from different causes and at various intervals, a professional anamnesis informing the doctor about the frequency and severity of seizures.
\end{abstract}

Keywords: multidisciplinarity, professional responsibility, neurological emergency epilepsy, oral-maxillofacial surgery.

Epilepsy is a chronic cerebral disease characterized by recurrent seizures that are motor, sensorial, behavioral, with a change in consciousness, includes partial and focal seizures (simple, motor,sensitive, sensorial, vegetative, psychic)[1-3].

Epilepsy presents groups of nerve cells, or neurons, that transmit abnormal signals; normal neuronal activity is disturbed, causing sensations, emotions or strange behaviors and sometimes seizures, muscle spasms and loss of consciousness.

Epilepsy is a disease that originates in the cerebral cortex, in the so-called gray matter, which is part of the central nervous system; is not a form of intellectual retardation or mental illness and it is not contagious. The appearance of epilepsy is characterized by the imbalance between inhibition and excitability, which leads to damage to the cortex that becomes thus hypexcitable and will have uncontrolled electrical activity [4-6].

Epilepsy is often the result of other diseases such as: cranial traumas, brain tumors, cerebral infections, strokes. The most common are the Jacksonian seizures that consist of tonic contractions localized to a member segment, have a whole membership. They are gradually propagated in the oil slick, and then secondary, they can be generalized, and transformed into a major crisis [7-9].

The epileptic crisis, the tonic form evolves with cerebral anoxia, the patient becomes cyanotic. It is unjustified and exaggerated the fear, the unusual panic that encompasses entourage at the sight of an epileptic seizure. A crisis is a sudden electrical discharge in the brain that usually affects the way a person feels or behaves for a short period of time. Crises are not a disease in themselves, but are a symptom of several factors that can affect the brain. Some crises can go almost unnoticed, while others are dramatic.

In fact, even the generalised tonico-clonic seizures or major crises, by far the most dramatic forms of paroxysmal epileptic manifestation, occur spontaneously, they develop and pass by themselves, some especially if they occur in sleep, remaining unaware of anyone[10-13].

The onset of epilepsy can be attributed to an internal neuronal stimulus, an external crash, medical injuries (such as cerebral vascular accidents, tumors) that hurtthe brain or deprive it of oxygen intake, but in most cases epilepsy has no identifiable cause (idiopathic epilepsy).

Untreated epilepsy changes the personality of the patient, and it is serious that sometimes he can commit acts of aggression, even crimes which the patient does not know he has done. Performing electroencephalography is absolutely essential in establishing the diagnosis and tracing the patient. This is done in shorter intervals at the onset of the disease, then less frequently, depending on the appearance and evolution of the disease clinics[1417].

Paroxysm appears as an expression of abnormal neuronal discharge of the brain. Very high frequency neuronal impulses are involved in this process, leading to an abnormal discharge of a large number of neurons. The two disorders hyperfrequency and hypersynchronization constitute the basic epileptic phenomenon. The paroxysmal diffusion of dysrhythmias leads to clinical focal access when diffusion is smaller or generalized when the diffusion is wide. The origin of the crisis can be cortical, subcortical, diencephalic, or centrocephalic[18-21].

In the mechanisms of the seizure discussing a trigger mechanism, a second mechanical way and a third stop mechanism of this crisis.

The trigger mechanism imposes epileptogenic eunoxia, a predisposition to epilepsy (which involves increased reactivity, increased convulsion, or low convulsive threshold) and trigger factors (precipitants) [22-24].

The brutality of epileptic irradiation is performed synaptically but also extrasinaptically (efaptically), irradiation being facilitated by a series of spatial and

*email cristibudacu@yahoo.com; cuciureanu57@gmail.com 
temporal desumption phenomena, the diffusion of the intraparoxic excitation is self-sustained by the effects of entrainment and reverberation[25-28].

Of the many factors and mechanisms that interfere directly or indirectly in the genesis of epileptic access, we quote: a neuronal epileptic with a subnormal bran potential, would be partially denerved because it brings repeated and frequent discharges to subliminal stimuli.

According to Ward (1969), the epileptogenic outbreak would be a partially disrupted aggregate of neurons in the cortex, in which the characteristic repetitive potentials appear and which either stimulate synaptically either by alterations in the local electric field or the ionic gradient bombarding by ortho or antidromo propagation neuronal cells, engaging them in epileptic activity [29-32].

This may be done by various factors: intense affection, local metabolic, vascular or even small non-degraded subclinical lesions.

Epileptogenic responsiveness focuses on the anticonvulsant predisposition resulting from a functional disorder in the brain electromagnetism, whose substrate of neuronal hyperexcitability and which in relation to age is higher in the child [33-35].

Epileptic access occurs in relation to epileptogenic noxes, which may be primarily cerebral, identifiable with the epileptic or extracerebral outbreak in the event that the paroxysmal manifestations are secondary to general processes, most commonly of a metabolic nature; the mechanism for the development of epileptic paroxysms is not fully elucidated, except for diffuse or partial seizures in which some Feed-Back mechanisms would occur; for the mechanism of stopping the epileptic crisis two factors are in discussion: progressive fatigue of neurons and an active inhibitory mechanism in which the talamo-caudal system would play a leading role [36-39].

It is possible that this inhibitory role on certain nervous circuits is mediated by chemical mediators such as gamma -amino-beta-hydroxybutyric acid while excitement of excitatory systems (oxygen depletion, decrease of free acetylcholine) with consecutive changes in intra and extracellular distribution sodium, potassium, calcium, magnesium ions [40-43].

\section{Experimental part}

\section{Material and method}

Our study was conducted in the Oral and Maxillofacial Surgery Clinic on 187 patients studied between 2015 and 2018. Of these, 171 were emergencies.

\section{Results and discussions}

General emergencies in the dental office do not have a very high frequency but can occur at any time and the correct and prompt reaction of the physician may and should allow their professional managementand therefore a proper dentist training and an appropriate patient evaluation[44-47].

The responsibility for decisions and consequences in these cases lies with the doctor, who has the professional, moral and forensic obligation to prevent urgency, to recognize it and to treat it properly, to know what he can do and not to do in these cases.

The risk assessment for the patient with dental conditions is of the highestimportance in the usual practice in the cabinet[48-51].

Idiopathic epilepsy is one that poses dental problems. It can evolve as the crisis: small $\rightarrow$ short-term absences, high $\rightarrow$ major epileptic crisis.

Triggering factors in the dental surgery may be diverse: odontogenic infections, dental neuralgia, alcohol abuse, work fatigue, reduction of anti epileptic medication, overdose of local anesthetics.

The clinical examination highlights Hydantoin gingival hyperplasia, multiple scarring on the tongue due to stroke during the seizures, facial expression can sometimes express a more or less advanced mental debility (as a result of brain destruction), for appreciation the risk of epileptic seizures, the frequency of seizures, the pre-emptive conditions, the date of the last crises must be specified and it is recommended that the patient stops the use of alchool but not interrupts the antiepileptic medication before the dental therapy [52-56].

With regard to patient interventions, it was observed that the most common neurological emergency in stomatology is epileptic seizure.

Emergency: place the patient on the floor, if possible, open the clothes, place the head on one side, place a rubber piece between the dental arches to avoid tussle, supervise the crisis;administration of $\mathrm{O}_{2}$ an injection of Fenobarbital $1-1.5 \mathrm{mg} / \mathrm{kg}$, Diazepam $10 \mathrm{mg}$ intravenously or intramuscularly.

If the patient has not regained consciousness and the cure is repeated, Diazepam $10 \mathrm{mg}$ intravenous will be administered, after which he will be hospitalized in an emergency hospital.

In the case of underlying seizures followed by a comatose state, the cardio-respiratory arrest can easily occur. In these situations the cardi-respiratory reanimation techniques are applied.

Establishing the diagnosis requires three important steps: knowing the patient, knowing the medical pathology and putting it in a precise nosological setting $[57,58]$.

Epileptic seizures are the result of excessive or abnormal activity of nerve cells in cortex in the brain. Generally, diagnosis involves removing other conditions that may cause similar symptoms (such as syncope) as well as identifying other immediate causes. Epilepsy can often be confirmed with an electroencephalogram.

From many types of epileptic seizures, the grand mal is the most serious. Usually it is recognized without difficulty because it has a typical onset.

The preconvulsive and convulsive phase include selfbiting of the tongue, sputum, urinary incontinence, and faeces, are pathognomonic signs of the grand mal crisis.

The postconvulsive phase manifests with confusion, twilight or deep sleep, retrograde amnesia, characteristic EEG changes. There are six main types of generalized convulsions: tonic-clonic, tonic crises, clonic, myoclonic, epileptic absence and atonic convulsions.All of these involve loss of consciousness and generally occurs without any warning. Tonic-clonic convulsions are manifested by a contraction of the limbs, followed by their stretching and arched back, having a duration of 10-30s (the tonic phase). During the contraction of the chest muscles, a scream can be heard. This is often followed by a trembling of the limbs in unison (clonal phase).

Tonic convulsions produce constant contractions of the muscles. In most cases, the person's skin turns blue, because breathing is interrupted. In the case of clonic seizures, limb shaking occurs in unison. After the end of trembling, the time ittakes for a person to return to a normal state is 10-30min; this period is called the period of enrollment.

The epileptic seizure on the dental armchair may, during dental care, involve various foreign bodies (fingerprints, endodontic instrumentation, easily detachable fillings, dental fragments, etc.) in the respiratory tract, causing total or partial obstruction. 
It is considered that genetics is a factor involved in most cases, either directly or indirectly [59].Some cases of epilepsy are due to a single gene defect (1-2\%); most cases are due to the interaction between multiple genes and environmental factors. Each of the single gene defects is rare, with a total of over 200 cases.

Some of the genes involved affect ionicchannels, enzymes GABA and receptors coupled with $\mathrm{G}$ protein. protein.

Emergencies were installed as follows: syncope-27 cases (15.78\%), allergic accidents - 19 cases (11.11\%), cardiociculators - 21 cases (12.28\%), other emergencies $01 \%)$; cerebral emergencies-epilepsy-39 cases (22.80\%)(Fig.1).

By gender there was revealed a higher number of women (February 2 patients-56.41\%) than men (17 patients, 43.59\%) (Fig.2).

Rural patients predominated over those in the urban environment, in a ratio of about 2/1.

Depending on the diagnosis, the oral surgery pathology for which surgery was performed was: acute apical periodontitis suppressed -17 patients (43.59\%), soft parts abcesses-8 patients $(20.51 \%)$, radicular remains- 14 patients (35.89\%) (Fig.3).
The moment of triggering the emergency-epilepsy crisis was performed during the intervention -63\%; after performing anesthesia-12\%; during anesthesia-22\%; at the entrance in the surgery-8\% (Fig.4).

In patients with epilepsy, general anesthesia with intravenous barbiturates is anesthesia of selection. If there are no conditions of general anesthesia or there is a disproportion between the importance of narcosis and the dental act, it is possible to perform loco-regional anesthesia that includes compulsory in premedication a pituitarypreferred parenteral (Fenobarbital) batch, in a dose that provides the hypnotic and anticonvulsant effect.

In the dental surgery, during specialized care, a series of consciousness disorders may occur, ranging from a confusing minor state to coma. These disturbances of the consciousness may take from a few seconds to a permanent status, translating severe brain injury.

Disturbances in the state of consciousness have a clinical polymorphic picture, whether they precede, accompany or follow the disturbances of respiratory function and / or cardio-circulatory function.

Tagging epilepsy diagnosis and determining what type of crises a patient may have is difficult. The epilepsy

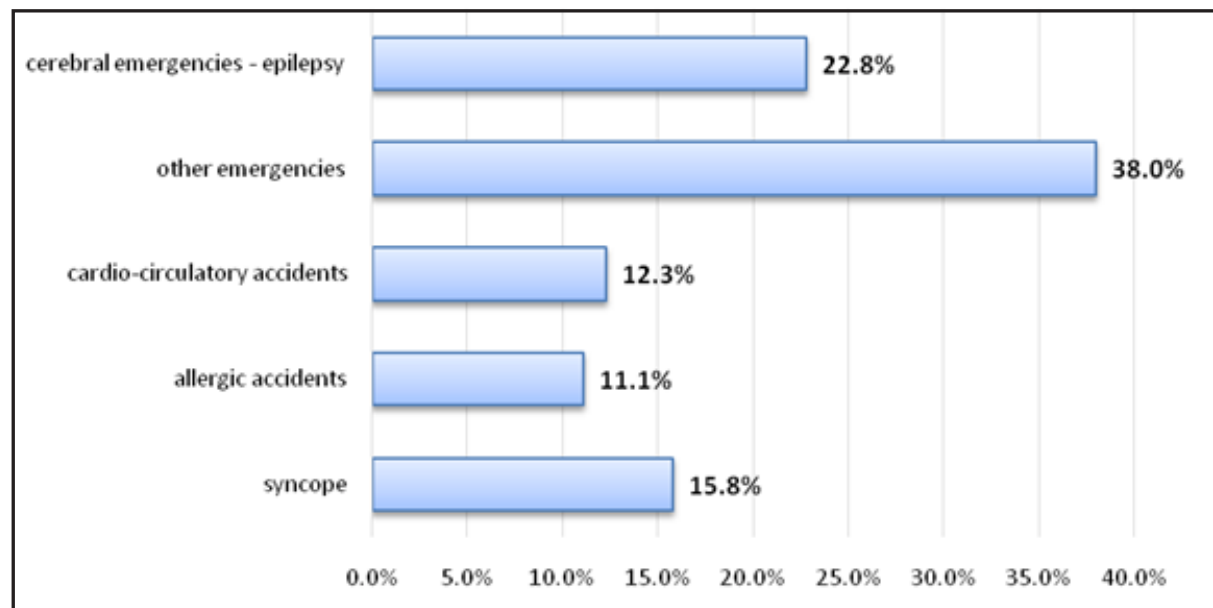

Fig.1 Distribution of emergencies according with oral surgery procedures

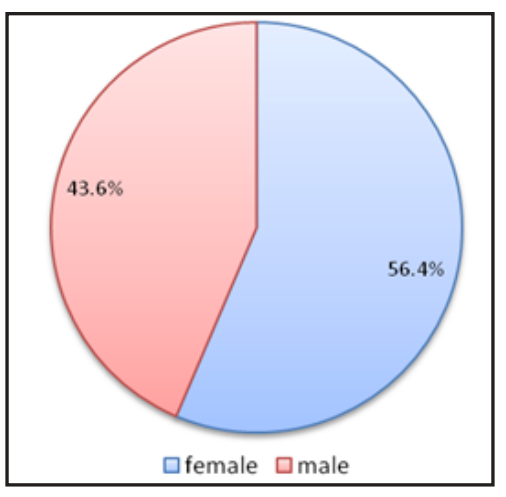

Fig. 2 Distribution by gender

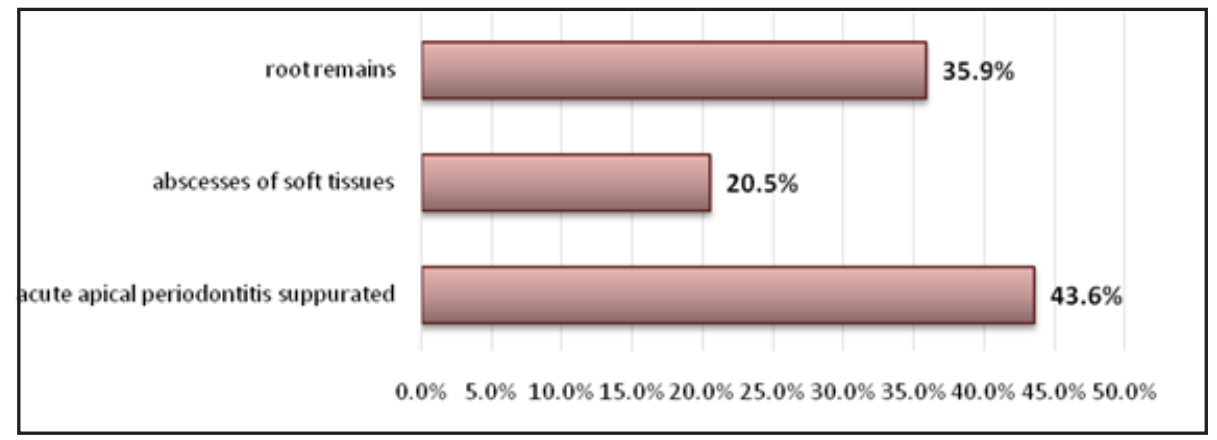

Fig.3. Incidence of oral pathology solved by oral surgery intervention

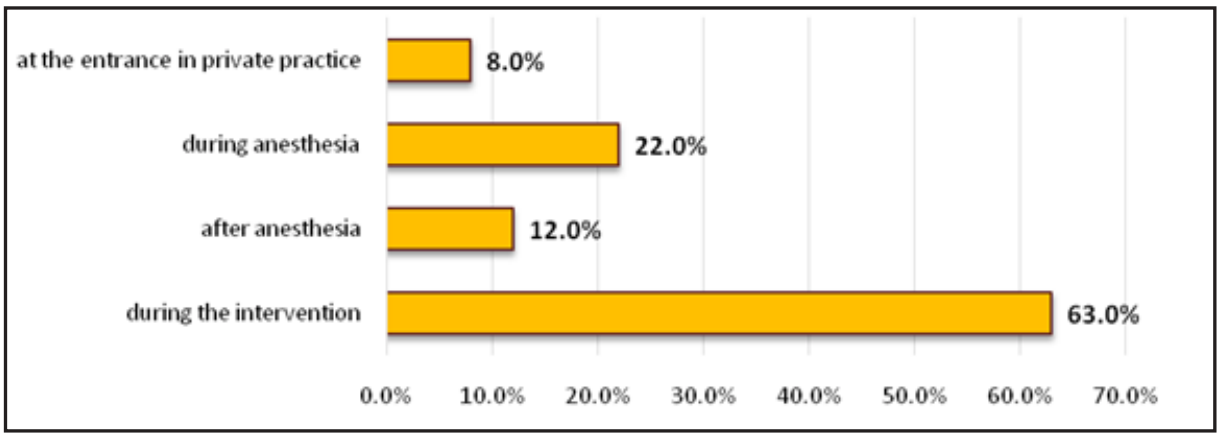

Fig.4 Prevalence of moment of epilepsy crisis according with oral surgery procedures 
diagnosis cannot and should not be considered a priori a drama. There are many cases of epileptic patients that did not prevent them from becoming prominent, and the research shows that $10 \%$ of the residents can get a better education and training. In addition, a properly administered and conscientiously administered treatment leads, in most cases, to the disappearance of crises, giving them the opportunity to embrace a very wide range of professions, of course avoiding activities involving risks of injury.

Prophylactic treatment: correct anamnesis, which notes that the patient is treated with antiepilectic preparations (Gabapentin, Pegabalin, Sodium valproate etc.) [60].

Schultze's statement that the epileptic suffers more from the attitude of the entourage than from his illness, it should be stressed that the atmosphere of calm and understanding that the entourage must manifest, the elimination of reserves and susceptibilities that oppose even the most intimate and natural desires of any common, not to be regarded as an unusual patient, are indispensable conditions for socioprofessional recovery to the maximum of its physical and mental resources

Success in treating and improving the quality of life the patient depends heavily on his precocity the accuracy of the clinical and electroencephalographic diagnosis of the disease.

\section{Conclusions}

In dental surgery, during the specialized care, a number of disturbances of consciousness can occur, ranging from minor to coma. This state of consciousness disturbance can last from a few seconds to a permanent status, they translating severe brain injury.

The epilepsy crisis (comitial seizures) occurs most frequently during the intervention, then during anesthesia.

\section{References}

1.MAGIORKINISE, KALLIOPI S, DIAMANTISA (ianuarie 2010). Hallmarks in the history of epilepsy: epilepsy in antiquity. Epilepsy \&behavior :E\&B. 17 (1) : 103-108.

2.CHANG BS, LOWENSTEIN DH (2003). Epilepsy. N. Engl. J. Med. 349 (13): 1257-66.

3.FISHER R, VAN EMDE BOAS W, BLUME W, ELGER C, GENTON P, LEE P, ENGEL J (2005). Epileptic seizures and epilepsy: definitions proposed by the International League AgainstEpilepsy (ILAE) and the International Bureau for Epilepsy (IBE) Epilepsia. 46 (4): 470-2.

4.EADIE, MJ (decembrie 2012). Shortcomings in the current treatment of epilepsy. Expert review of neurotherapeutics. 12 (12): 1419-27. 5.THURMAN, DJ (septembrie 2011). Standards for epidemiologic studies and surveillance of epilepsy. Epilepsia. 52 Suppl 7: 2-26.

6.BRODIE, MJ (noiembrie 2009). Epilepsy in later life. Lancet neurology. 8 (11): 1019-30.

7.HOLMES, THOMAS R. BROWNE, GREGORY L. (2008). Handbook of epilepsy (ed. 4th). Philadelphia: Lippincott Williams \& Wilkins p.7. 8.***Wyllie's treatment of epilepsy : principles and practice (ed. 5th). Philadelphia: Wolters Kluwer/Lippincott Williams \& Wilkins. 2010.

9.NEWTON, CR (29 septembrie 2012). Epilepsy in poor regions of the world. Lancet. 380 (9848): 1193-201.

10.WILDEN, JA (15 august 2012). Evaluation of first nonfebrile seizures. American family physician. 86 (4).

11.BERG, AT (2008). Risk of recurrence after a first unprovoked seizure. Epilepsia. 49 Suppl 1: 13-8.

12.L DEVLIN, A (decembrie 2012). Epilepsy and driving: current status of research. Epilepsy research. 102 (3).

13.DUNCAN, JS (1 aprilie 2006). Adult epilepsy (PDF). Lancet. 367 (9516): 1087-100.
14.***National Institute for Health and Clinical Excellence (ianuarie 2012). Chapter 1: Introduction. The Epilepsies: The diagnosis and management of the epilepsies in adults and children in primary and secondary care (PDF). National Clinical Guideline Centre. pp. 2128.

15. HAMMER, edited by Stephen J. McPhee, Gary D. (2010). 7. Pathophysiology of disease: an introduction to clinical medicine (ed. 6th ed.). New York: McGraw-Hill Medical. ISBN 978-007-162167-0.

16.HUGHES, JR (august 2009). Absence seizures: a review of recent reports with new concepts. Epilepsy \&behavior : E\&B. 15 (4): 40412.

17.BRADLEY, WALTER G. (2012). 67. Bradley's neurology in clinical practice (ed. 6th ed.). Philadelphia, PA: Elsevier/Saunders. ISBN 9781-4377-0434-1.

18.ENGEL, JEROME (2008). Epilepsy: a comprehensive textbook (ed. 2nd ed.). Philadelphia: Wolters Kluwer Health/Lippincott Williams \& Wilkins. p. 2797.

19.SIMON, DAVID A. GREENBERG, MICHAEL J. AMINOFF, ROGER P. (2012). 12. Clinical neurology (ed. 8th ed.). New York: McGraw-Hill Medical.

20.STEVEN C. SCHACHTER, ed. (2008). Behavioral aspects of epilepsy : principles and practice (ed. [Online-Ausg.].). New York: Demos. p. 125.

21.XUE, LY (martie 2006). Reflex seizures and reflex epilepsy. American journal of electroneurodiagnostic technology. 46 (1) : 39-48.

22.MALOW, BA (noiembrie 2005). Sleep and epilepsy. Neurologic Clinics. 23 (4) : 1127-47.

23.TINUPER, P (august 2007). Movement disorders in sleep: guidelines for differentiating epileptic from non-epileptic motor phenomena arising from sleep. Sleep medicine reviews. 11 (4): 255-67

24.HOLMES, THOMAS R. (2008). Handbook of epilepsy (ed. 4th ed.). Philadelphia: Lippincott Williams \& Wilkins. p. 34.

25.PANAYIOTOPOULOS, CP (2010). A clinical guide to epileptic syndromes and their treatment based on the ILAE classifications and practice parameter guidelines (ed. Rev. 2nd ed.). [London]: Springer. p. 445.

26.J AMES W. WHELESS, ed. (2009). Advanced therapy in epilepsy. Shelton, Conn.: People's Medical Pub. House. p. 443.

27.LARNER, ANDREW J. (2010). A dictionary of neurological signs (ed. 3rd ed.). New York: Springer. p. 348.

28.STEFAN, HERMANN (2012). Epilepsy Part I: Basic Principles and Diagnosis E-Book: Handbook of Clinical Neurology (ed. Volume 107 of Handbook of Clinical Neurology). Newnes. p. 471.

29.PLIOPLYSS, DUNN DW, CAPLAN R (2007). 10-year research update review: psychiatric problems in children with epilepsy. J Am Acad Child Adolesc Psychiatry. 46 (11): 1389-402.

30.REILLY CJ (2011). Attention Deficit Hyperactivity Disorder (ADHD) in Childhood Epilepsy. Research in Developmental Disabilities: A Multidisciplinary Journal. 32 (3): 883-93.

31.LEVISOHN PM (2007). The autism-epilepsy connection. Epilepsia. 48 (Suppl 9): 33-5.

32.BERG, AT (aprilie 2010). Revised terminology and concepts for organization of seizures and epilepsies: report of the ILAE Commission on Classification and Terminology, 2005-2009. Epilepsia. 51 (4) : 67685)

33.NELIGAN, A (2012). The epidemiology of the epilepsies. Handbook of clinical neurology. 107: 113-33.

34.PANDOLFO, M. (2011). Genetics of epilepsy. Semin Neurol. 31 (5): 506-18.

35.DHAVENDRA KUMAR, ed. (2008). Genomics and clinical medicine. Oxford: Oxford University Press. p. 279.

36.BHALLA, D.; GODET, B.; DRUET-CABANAC, M.; PREUX, PM. (2011). Etiologies of epilepsy: a comprehensive review. Expert Rev Neurother. 11 (6): 861-76.

37.SIMON D. SHORVON (2011). The Causes of Epilepsy: Common and Uncommon Causes in Adults and Children. Cambridge University Press. p. 467. 
38.SELLNER, J (2012 Oct). Seizures and epilepsy in herpes simplex virus encephalitis: current concepts and future directions of pathogenesis and management. J ournal of neurology. 259 (10): 201930.

39.GOLDBERG, EM (mai 2013). Mechanisms of epileptogenesis: a convergence on neural circuit dysfunction. Nature reviews. Neuroscience. 14 (5): 337-49.

40.OBY, E (noiembrie 2006). The blood-brain barrier and epilepsy. Epilepsia. 47 (11): 1761-74.

41.J EROME ENGEL, JR., TIMOTHY A. PEDLEY, ed. (2008). Epilepsy : a comprehensive textbook (ed. 2nd ed.). Philadelphia: Wolters Kluwer Health/Lippincott Williams \& Wilkins. p. 483.

42.PANAYIOTOPOULOS, CP (decembrie 2011). The new ILAE report on terminology and concepts for organization of epileptic seizures: a clinician's critical view and contribution. Epilepsia. 52 (12) : 215560.

43.CIOCAN-PENDEFUNDA,A.A.,MARTU,M.A.,ANTOHE,M.E.et al.,Indirect composite veneers as a social therapeutic solution.A case report, Romanian Journal Of Oral Rehabilitation,10 (4), 2018, P:9196

44.IFTENI,G.,APOSTU,A., TANCULESCU,O., Dental occlusions and the importance of its proper investigation-Part I, Romanian J ournal of Oral Rehabilitation, 8(2),2016, Pages: $94-100$

45. PETCU,A.,SAVIN ,C.,BALAN,A.,Biomaterials involved in frontal area restorations in pediatric dentistry,Biomaterials Involved in Frontal Area Restorations in Pediatric Dentistry,Rev.Chim.(Bucharest),69, no.12, 2018 p. 3473-3476

46. EARAR,K.,ANTONIAC,V.I.,BACIU,S., Etching Treatment Effect on Surface Morphology of Dental Structures,Rev.Chim.(Bucharest),68, no.11,2017, p. 2700-2703

47.SOMJEN, GEORGE G. (2004). Ions in the Brain Normal Function, Seizures, and Stroke. New York: Oxford University Press. p. 167

48. DROCHIOI,C., COSTAN,V.V., ZAHARIA, M., et al., FT-IR Characterization of Some Biological Materials Used in Reconstructive Surgery, Rev.Chim.(Bucharest), 66, no.9,2015, p.1302-1305

49.HRISTIAN, L., BORDEIANU, D.L., IUREA, P., et al., Study of the Tensile Properties of Materials Destined to Manufacture Protective Clothing for Firemen, Mat. Plast., 51, no. 4,2014, p. 405-409

50.EARAR, K., GRADINARU,S., PARIZA,G., et al., Effect of the Sterilization Procedures of Different Surgical Meshes for Abdominal Surgery, Rev. Chim.(Bucharest), 68, no.8, 2017, p. 1868-1873
51.DASCALU, C.G., ANTOHE, M.E., GOLOVCENCU L., et al.,Interaction Schemes for the Analysis of Combined Action of Risk Factors, 2017 IEEE INTERNATIONAL CONFERENCE ON E-HEALTH AND BIOENGINEERING CONFERENCE (EHB) Book Series: E-Health and Bioengineering Conference, 2017, Pages: 462-465

52.GRADINARU, I., ANTOHE M.E., HURJUI, L.L,Biomaterials used in oral rehabilitation of the edentulous allergic patients, Romanian J ournal of Oral Rehabilitation,10(1),2018, Pages: 114-119

53.ESANU, I., DEBITA, M., DOROBAT, C.M., et al., Chemical and Biological Factors in Infectious Diseases The oral microbial flora, Rev.Chim.(Bucharest), 70,no.4, 2019, p. 1420-1423

54.LUPUSORU, R.V., TOPOR, G., MIRON, I.C., et al., Chemical Factors which Prompt Oral Pathological Phenomena In Some Nutrition Diseases, Rev. Chim.(Bucharest), 70, no.5,2019, p. 1884-1887

55.OLARIU, L., DUMITRIU,B., CRACIUN,L., et al., The in vitro influence of a pharmaceutically active small sea fish extract on a apoptosis and proliferation mechanisms amplified by inflammatory conditions, Farmacia, 66(3), 2018, Pages: 524-529

56.BADIU, D., RONCEA,F., ROSOIU, N., Formulation and pharmaceutical evaluation of three W/O emulsions with Mytilus Galloprovincialis LMK. and Rapana Venosa lipid extracts, Farmacia, 57(2), 2009,Pages: 212-217

57.CUCIUREANU, D. I.; CONSTANTINESCU, I. MOISEI; DANCIU, F.; et al Brain tuberculomas revealed by epileptic generalized seizures after tuberculostatic treatment: a case report, Conference: 31st International Epilepsy Congress Location: Istanbul, Turkey sep 0509,2015, EPILEPSIA Volume: 56 Special Issue: SI Supplement: 1 Pages: 128 MeetingAbstract: p0516 Published: FEB 2015

58.CUCIUREANU, D. I. CUCIUREANU, T., Neurotic disorder and unexpected EEG records in apparenthealthy people, Conference: 23rd World Congress of Neurology (WCN) Location: Kyoto, JAPAN Date: SEP 16-21, 2017 J OURNAL OF THE NEUROLOGICAL SCIENCES Volume: 381 Supplement:S Pages: 339-339 Meeting Abstract: 935 Published: OCT 152017

59.RAFTU, GHEORGHE; DEBITA, MIHAELA; DINU, CIPRIAN; etal. The Role of Chemical Factors in the Occurrence of the Nervous System Disorders Posttraumatic epilepsy, Rev. Chim. (Bucharest), 70, no. 1, p. 228-232

60.BOANGHER, SABINA; MESPOUILLE, PASCAL; GOFFETTE, SOPHIE; et al., Herpes simplex encephalitis relapse associated with positive $\mathrm{N}$-methyl-d-aspartate receptor antibodies, ACTA NEUROLOGICA BELGICA Volume: 118 Issue: 4 Pages: 533-535 Published: DEC 2018

Manuscript received: 30.01 .2019 